\title{
PENGARUH PROFESIONALISME DAN KOMPETENSI PENGAWASAN INTERNAL TERHADAP KUALITAS AUDIT PADA INSPEKTORAT PROVINSI BANTEN
}

\author{
Ulvia Fadilah', Eka Mahmudin $\mathbf{S}^{2}$ \\ Public Administration Magister Program Sultan Ageng Tirtayasa University ${ }^{1}$, \\ Banten Province Department of Energy and Mineral Resources ${ }^{2}$ \\ Serang Indonesia \\ ulvia_cute@yahoo.com ${ }^{1}$,ekams0109@gmail.com²
}

\begin{abstract}
This study aimed to examine the effect of professionalism and competence of internal supervision on audit quality at the Banten Provincial Government Inspectorate. This research developed a theoretical framework as a basis for hypotheses, to answer research questions consisting of how professionalism influences audit quality, and how competence influences audit quality. The samples of this study were 83 Government Internal Examiners (APIP) at the Inspectorate of Banten Province. This research used census method. The data used are primary data collected through questionnaires. Data analysis method to test hypotheses was Structural Equation Modeling (SEM) analysis using Partial Least Square (PLS). The results of this study indicate that: (1) professionalism hada positive and significant effect on audit quality, and (2) Competence had a positive and significant effect on audit quality.
\end{abstract}

Keywords : Professionalism, Competence, and Audit Quality.

\section{PENDAHULUAN}

Pengawasan internal yang dilakukan oleh Aparat Pengawasan Intern Pemerintah (APIP) yang terdapat dalam Peraturan Pemerintah Republik Indonesia Nomor 60 tahun 2008 Pasal 1 ayat 3 menyatakan Sistem Pengendalian Intern Pemerintah (SPIP) terdiri dari audit, reviu, evaluasi, pemantauan dan kegiatan pengawasan lainnya. Pengawasan bersifat membantu agar sasaran yang ditetapkan organisasi dapat tercapai, dan secara dini menghindari terjadinya penyimpangan pelaksanaan, penyalahgunaan wewenang, pemborosan dan kebocoran. Kualitas audit merupakan hal penting, karena dengan kualitas audit yang baik secara sinergi dapat menghasilkan laporan audit yang dapat dipercaya sebagai dasar pengambilan keputusan (Arens et.al., 2014). De Angelo (1981) menyebutkan bahwa kualitas audit sebagai probabilitas, yaitu seorang auditor menemukan dan melaporkan tentang adanya suatu pelanggaran dalam sistem akuntansi kliennya. Auditor yang berkompeten dan profesional diharapkan 
dapat menghasilkan kualitas audit yang baik.

Berkaitan dengan pemeriksaan atas pengelolaan dan tanggung jawab keuangan negara, dalam pasal 9 ayat (1) UndangUndang Nomor 15 Tahun 2004 disebutkan bahwa dalam menyelenggarakan pemeriksaan pengelolaan tanggung jawab keuangan negara, Badan Pemeriksa Keuangan (BPK) dapat memanfaatkan hasil pemeriksaan Aparat Pengawasan Internal Pemerintah (Wakhyudi, 2012). Kewajiban Aparat Pengawasan Internal Pemerintah (APIP) adalah untuk melaksanakan review (pemeriksaan) atas laporan keuangan pemerintah daerah sebelum disampaikan kepada BPK untuk diaudit, akan tetapi pelaksanaan pemeriksaan tersebut sampai saat ini belum sepenuhnya dapat meningkatkan efektivitas kualitas audit.

Berdasarkan hasil kegiatan Asistensi Self Assessment kompetensi dan kapabilitas APIP pada Inspektorat Provinsi Banten yang dilaksanakan oleh Badan Pengawasan Keuangan dan Pembangunan (BPKP) Perwakilan Provinsi Banten tahun 2019, menyatakan bahwa APIP pada Inspektorat Provinsi Banten masih berada pada Level 2, dengan demikian hasil evaluasi ini masih belum memenuhi amanat dari RPJMN yang mengharuskan semua APIP baik di Pemerintah Pusat maupun Daerah untuk berada di Level 3.

Untuk mewujudkan kualitas audit yang baik perlu didukung oleh beberapa faktor yang berkaitan dengan audit, yaitu salah satunya kompetensi (Schelker, 2012). Kualitas audit yang baik juga dipengaruhi secara signifikan oleh profesionalisme auditor yang baik (Susilawati, 2016). Berbeda dengan penelitian sebelumnya Fietoria (2016) menyatakan bahwa profesionalisme tidak berpengaruh secara signifikan terhadap kualitas audit. Penelitian lainnya, Maharany et.al., 2016 menyatakan bahwa kompetensi tidak memberikan pengaruh yang signifikan terhadap kualitas audit. Beberapa penelitian sebelumnya telah menggunakan pendekatan yang berbeda dalam meneliti faktor-faktor yang memengaruhi kualitas (Arena dan Azzone, 2009) dan sampai sekarang belum ada konsensus mengenai kerangka kerja yang paling tepat untuk meneliti efektivitas kualitas, dengan demikian tema mengenai kualitas audit masih merupakan proses dinamis dan masih menjadi bahan perdebatan (Endaya dan Hanefah, 2013).

Perbedaan hasil dari beberapa penelitian tersebut terkait dengan tema kualitas audit di lingkungan pemerintahan yang dipengaruhi oleh faktor kompetensi 
dan profesionalisme yang memengaruhi kualitas audit masih cukup menarik untuk diteliti lebih lanjut. Penelitian-penelitian tentang hal yang terkait dengan faktorfaktor yang memengaruhi kualitas audit sudah banyak dilakukan seperti yang telah diuraikan di atas. Akan tetapi berdasarkan temuan hasil pemeriksaan BPK RI pada IHPS BPK RI Semester II Tahun 2019, dan evaluasi terhadap APIP oleh BPKP masih menunjukkan kelemahan secara signifikan termasuk di lingkungan Inspektorat Pemerintah Provinsi Banten. Berdasarkan alasan tersebut maka faktorfaktor yang memengaruhi kualitas audit masih menarik untuk diteliti.

Pelaksanaan pemeriksaan dan penyusunan laporan audit, pemeriksa wajib menggunakan kemahiran profesionalnya dengan cermat dan seksama yang tercantum dalam standar umum yang pertama dalam Standar Profesional Akuntan Publik (SPAP) yang ditetapkan oleh Ikatan Akuntan Indonesia (Al Haryono Jusuf, 2001). Menurut Sedarmayanti (2004) bahwa profesionalisme adalah suatu sikap atau keadaan dalam melaksanakan keadaan dalam melaksanakan pekerjaan dengan memerlukan keahlian melaului pendidikan atau latihan tertentu, dan dilakukan sebagai suatu pekerjaan yang memiliki sumber penghasilan. Dalam mengukur variabel profesionalisme pada penelitian ini menggunakan beberapa indikator terkait profesionalisme, yaitu kemampuan, efektifitas, efisiensi dan tanggung jawab.

Al Haryono Jusuf (2001) menyatakan bahwa Kompetensi Auditor Internal diperoleh melalui pendidikan dan pengalaman. Sementara Hitt et al.,(1999) menyatakan "Competence is combination of knowledge, skills, attitudes and experience" Kompetensi adalah merupakan gabungan dari pengetahuan, keterampilan, sikap, dan pengalaman. Dari berbagai pendapat di atas dapat disimpulkan bahwa indikator indikator tentang kompetensi pada prinsipnya terdiri dari Pengetahuan, Keterampilan, Sikap dan Pengalaman.

The Institute of Internal Auditors (2011) mendefinisikan kualitas sebagai metode untuk pemeriksaan dan melakukan investigasi. Kualitas audit dapat ditentukan dari praktek atau proses kerja audit. Menurut Arens et al. (2012) kualitas audit merupakan: How tell an auditor detects and report material misstatements in financial statements. Bagaimana seorang auditor dapat mendeteksi dan melaporkan pelanggaran yang material di laporan keuangan. Pendapat yang sama dikemukakan oleh DeAngelo (1981) yang mendefinisikan kualitas audit sebagai: To 
be market-assessed joint probabilitiy that a given auditor will both (a) discoxer a breach in the clients accounting system, and (b) report the breach. Probabilitas auditor dapat mendeteksi salah saji material dan melaporkan pelanggaran tersebut dengan baik kualitas audit sebagai probabilitas nilaian pasar bahwa laporan keuangan mengandung kekeliruan material dan auditor akan menemukan dan melaporkannya

Auditor dalam melaksanakan audit harus berpedoman pada standar audit yang ditetapkan oleh Ikatan Akuntan Publik Indonesia (IAPI) yakni standar umum, standar pekerjaan lapangan dan standar pelaporan. Selain standar audit, seorang auditor juga harus mematuhi kode etik profesi yang mengatur tentang tanggung jawab profesi, kompetensi dan kehatihatian professional, kerahasiaan, perilaku profesional serta standar teknis bagi seorang auditor dalam menjalankan profesinya. Menurut Arens \& Loobecke (2009) profesionalisme adalah suatu tanggung jawab yang dibebankan lebih dari sekedar dari memenuhi tanggung jawab yang dibebankan kepadanya dan lebih dari sekedar dari memenuhi Undangundang dan peraturan masyarakat. Fietoria dan Manalu (2016) menyatakan bahwa profesionalisme, secara parsial tidak berpengaruh secara signifikan terhadap kualitas audit, sedangkan secara simultan profesionalisme berpengaruh terhadap kualitas audit. Kemudian Susilawati (2014) menyatakan hal yang berbeda dengan penelitian sebelumnya yaitu profesionalisme berpengaruh signifikan terhadap Kualitas Audit secara simultan. Sedangkan secara parsial, Profesionalisme berpengaruh positif dan signifikan terhadap Kualitas Audit. Berdasarkan uraian pendapat dari beberapa hasil penelitian di atas masih terdapat perbedaan hasil penelitian mengenai profesionalisme terhadap kualitas audit, namun demikian sebagian besar menyatakan bahwa kualitas audit dipengaruhi oleh profesionalisme, dengan demikian masih cukup menarik untuk dilaksanakan penelitian kembali terkait dengan pengaruh profesionalisme terhadap kualitas audit. Maka dapat disusun hipotesis untuk penelitian ini sebagai berikut:

\section{$\mathrm{H}_{1}$ : Terdapat pengaruh positif dan signifikan profesionalisme terhadap kualitas audit}

Schelker (2012) menyatakan bahwa kompetensi auditor berpengaruh positif signifikan terhadap kualitas audit dan peningkatan akurasi informasi keuangan yang disampaikan kepada publik. Sejalan dengan hal tersebut Fauziah 
menyatakan bahwa kompetensi berpengaruh positif secara signifikan terhadap kualitas audit, sehingga semakin baik tingkat kompetensi, maka akan semakin baik kualitas audit yang dihasilkan. Selanjutnya Karnisa (2015) menyatakan bahwa kompetensi berpengaruh positif terhadap kualitas audit. Kemudian Rosalina (2015), mendukung penelitian sebelumnya, hasil penelitiannya menyatakan bahwa kompetensi auditor berpengaruh secara signifikan terhadap kualitas audit. Sementara itu penelitian Maharany et al., (2016), menyatakan bahwa kompetensi tidak memberikan pengaruh yang signifikan terhadap kualitas Audit. Berdasarkan beberapa hasil penelitian di atas dapat disimpulkan bahwa sebagian besar menyatakan terdapat pengaruh positif antara kompetensi terhadap kualitas audit, sehingga dapat disusun hipotesis sebagai berikut:

\section{$\mathrm{H}_{2}$ : Terdapat pengaruh positif dan signifikan kompetensi terhadap kualitas hasil audit.}

Gambar 1. Kerangka Pemikiran

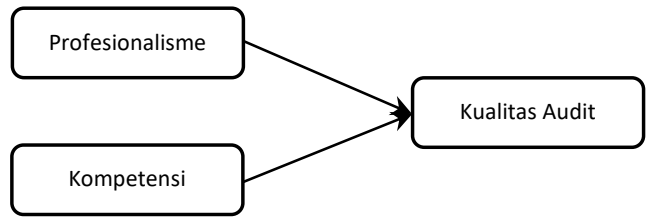

\section{METODE PENELITIAN}

Populasi pada penelitian ini adalah seluruh APIP di lingkungan Inspektorat Provinsi Banten yang berjumlah 83 orang. Teknik penarikan sampel dalam penelitian ini adalah dengan menggunakan sampel jenuh atau metode sensus. Teknik tersebut dipilih karena peneliti mempunyai pertimbangan jumlah seluruh auditor dan aparat pengawas pada Inspektorat Provinsi Banten masih relatif sedikit dan bisa dijadikan sebagai sampel seluruhnya.

Teknik Pengumpulan data pada penelitian ini menggunakan kuesioner yang dibagikan kepada masing-masing responden sebagaimana sampel yang telah ditetapkan. Definisi operasional variabel pada penelitian ini adalah sebagai berikut :

1. Profesionalisme (X1). Profesionalisme adalah tanggungjawab untuk berperilaku yang lebih dari sekedar memenuhi tanggungjawab yang dibebankan kepadanya dan lebih dari sekedar memenuhi undang-undang dan peraturan masyarakat.

2. Kompetensi (X2) Kompetensi dalam pengauditan merupakan pengetahuan, keahlian, dan pengalaman yang dibutuhkan auditor untuk dapat melakukan audit secara objektif, 
cermat dan seksama. Kompetensi auditor diukur dengan menggunakan enam item pernyataan yang menggambarkan tingkat persepsi auditor terhadap bagaimana kompetensi yang dimilikinya terkait standar akuntansi dan audit yang berlaku, penguasaannya terhadap seluk beluk organisasi pemerintahan, serta program peningkatan keahlian. Responden diminta menjawab tentang bagaimana persepsi mereka, memilih di antara lima jawaban mulai dari sangat setuju sampai ke jawaban sangat tidak setuju. Masing-masing item pernyataan tersebut kemudian diukur dengan menggunakan Skala Likert 5 poin, di mana poin 1 diberikan untuk jawaban yang berarti kompetensi paling rendah, dan seterusnya poin 5 diberikan untuk jawaban yang berarti kompetensi paling tinggi.

3. Kualitas Audit/hasil pemeriksaan (Y). Kualitas Audit adalah suatu dokumen yang merupakan media bagi auditor untuk menyatakan tujuan dan ruang lingkup auditnya serta melaporkan temuan-temuan dan kesimpulankesimpulan audit berikut saran (rekomendasi) perbaikan yang memenuhi unsur-unsur kualitas

laporan hasil pemeriksanaan.

Metode analisis data pada penelitian ini menggunakan metode analisis kuantitatif. Analisis data dilaksanakan setelah data dari seluruh responden atau sumber data lain terkumpul. Teknik analisis yang digunakan menggunakan statistik deskriptif. Statistik deskriptif bertujuan untuk memberikan gambaran secara kuantitatif tentang rangkuman pengamatan terhadap setiap variabel penelitian yang secara umum menguraikan tentang ukuran dan sebaran dari setiap variabel penelitian seperti apa adanya tanpa bermaksud untuk membuat kesimpulan yang berlaku untuk umum atau generalisasi. Analisis deskriptif data setiap variabel penelitian dilakukan terhadap variabel mandiri, yaitu tanpa membuat perbandingan atau menggabungkan dengan variabel lain. Analisis deskriptif menggunakan bentuk tabel jumlah skor dan persentase. Analisis deskriptif data setiap variabel penelitian menggunakan kriteria skor tanggapan responden. Kategorisasi skor tanggapan responden dalam penelitian ini menggunakan kategorisasi jenjang merujuk kepada Narimawati (2010). Ketegorisasi bersifat relatif, maka luas interval dapat ditetapkan secara subyektif yang mencakup setiap 
kategori yang diinginkan selama penetapan tersebut berada dalam batas kewajaran dan dapat diterima akal sehat (common sense). Skor digolongkan menjadi 5 kategori yaitu Tidak Baik, Kurang Baik, Cukup Baik, Baik, dan Sangat Baik.

Selanjutnya statistik inferensial merupakan teknik statistik yang digunakan untuk menganalisis data sampel dan hasilnya akan diberlakukan untuk populasi (generalisasi) melalui pengujian taraf signifikansi data sampel (meskipun tidak menjadi fokus utama dalam penggunaan partial least square-path modeling) terhadap parameter populasinya melalui uji t (t-statistic) pada tarif keyakinan (confidence interval) sebesar $95 \%$ dan risiko kesalahan pada $\alpha=5 \%$. Hasil analisis ini dapat digunakan untuk mengetahui pengaruh antara variabel eksogen terhadap endogen. Untuk tujuan analisis data, pola hubungan antara variabel eksogen dan endogen dalam penelitian ini menggunakan pendekatan Partial Least Square-Path Modeling (PLS-PM). PLS dapat digunakan untuk mengkonfirmasi teori dan menjelaskan ada atau tidaknya hubungan antar variabel laten. Oleh karena lebih menitikberatkan pada data dan dengan prosedur estimasi yang terbatas, maka mispesifikasi model tidak begitu berpengaruh terhadap estimasi parameter.
Kelebihan PLS adalah dapat menganalisis sekaligus konstruk yang dibentuk dengan indikator refleksif dan indikator formatif.

\section{HASIL PENELITIAN DAN PEMBAHASAN}

Berdasarkan hasil Output SmartPLS dapat dilihat hasil pengolahan data sebagai berikut:

\section{Gambar 2 : Model PLS Hasil Uji Signifikansi Koefisien}

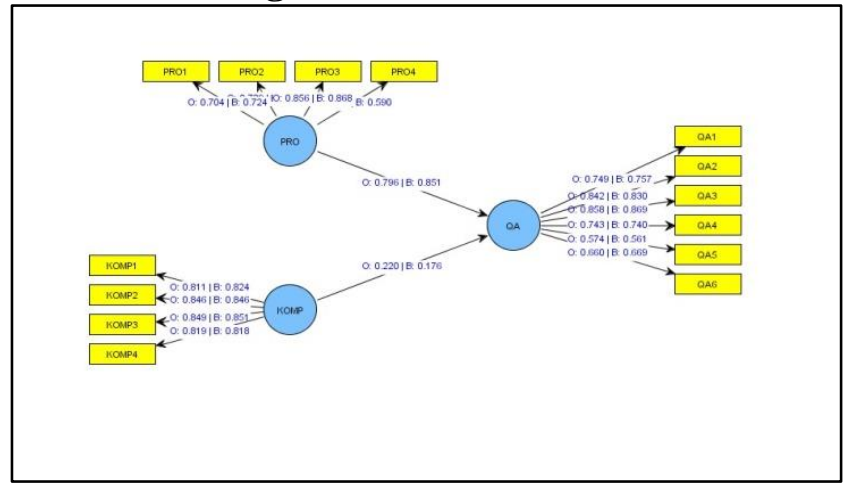

Berikutnya hasil uji koefisien dapat dilihat pada tabel di bawah ini:

Tabel 1 : Path Coefficients Antar Variabel dan Uji Signifikansi

\begin{tabular}{rrrr}
$\begin{array}{c}\text { original } \\
\text { sample } \\
\text { estimate }\end{array}$ & $\begin{array}{c}\text { mean of } \\
\text { subsamples }\end{array}$ & $\begin{array}{r}\text { standard } \\
\text { deviation }\end{array}$ & T-statistic \\
\hline 0,796 & 0.851 & 0,034 & 23,404 \\
0,220 & 0,176 & 0,036 & 6,079 \\
\hline
\end{tabular}

Sumber : Data diolah, 2020

Hasil uji signifikansi koefisien jalur pada model struktural menunjukkan bahwa variabel profesionalisme berpengaruh positif dan signifikan terhadap kualitas audit. Hal ini dibuktikan oleh nilai $t$ statistik yang diperoleh lebih besar dari 
$1,96(23,404>1,96)$. Pada penelitian ini profesionalisme diukur oleh 4 indikator yaitu kemampuan, efektifitas, efisiensi dan tanggung jawab. Indikator kemampuan merupakan indikator yang paling dominan dalam indikator variabel penelitian ini.

Hal ini menunjukkan bahwa auditor di lingkungan Inspektorat Provinsi Banten mampu dengan baik melaksanakan penugasan audit sesuai dengan kertas kerja yang telah disusun sebelumnya, serta memiliki tanggung jawab yang sangat baik, yang dibuktikan dengan auditor mau bekerja di atas batas normal untuk menyelesaikan penugasan audit yang telah diberikan dan akan menjadi kepuasan batin tersendiri apabila tugas tersebut dapat diselesaikan dengan baik. Kondisi riil profesionalisme auditor dari aspek kemampuan auditor dalam melaksanakan penugasan audit di lingkungan Pemerintah Provinsi Banten dinilai sudah cukup memiliki kemampuan. Hal ini dibuktikan dengan hasil laporan audit yang dilaksankan oleh para auditor di lingkungan Inspektorat Provinsi Banten sudah sesuai dengan program kerja audit dan kertas kerja audit yang telah disusun sebelumnya. Seiring dengan meningkatnya kemampuan auditor dalam melaksanakan penugasan dengan baik maka profesionalisme auditorpun semakin meningkat sehingga kualitas audit yang dihasilkanpun semakin baik dan dapat dipergunakan untuk kepentingan stakeholder, salah satunya yaitu dapat digunakan untuk memudahkan proses audit yang dilaksanakan oleh auditor eksternal yaitu BPK RI.

Kemudian dari aspek efisiensi secara umum auditor di lingkungan Inspektorat pemerintah Provinsi Banten dalam melaksanakan tugasnya sudah sesuai dengan standar waktu dan standar kualitas audit yang telah ditetapkan sebelumnya, terlebih lagi sekarang ini pemerintah Provinsi Banten sudah mulai merancang melaksanakan sistem e-audit yaitu proses audit yang berbasis teknologi sistem informasi berdasarkan hasil rekomendasi dari BPK RI serta pendampingan oleh Komisi Pemberantasan Korupsi (KPK). Demikian halnya dengan indikator sebelumnya indikator efisiensi dalam mengukur profesionalisme auditor di lingkungan Inspektorat Provinsi Banten juga sudah cukup baik. Hal ini dibuktikan dengan kondisi riil auditor di lingkungan Inspektorat Provinsi Banten sudah cukup efisien dalam melaksanakan penugasan audit, yaitu dengan sudah mulai menggunakan e-audit berdasarkan database simral yang digunakan dalam perencanaan, pengelolaan, serta pelaporan 
keuangan. Hasil audit dengan pola $e$-audit ini terbukti efisien dan dapat digunakan oleh BPK RI dalam melaksanakan audit atas LKPD Provinsi Banten Tahun Anggaran 2019 dengan demikian profesionalisme auditor di lingkungan Inspektorat Provinsi Banten dari aspek efisiensi sudah cukup baik dan dapat dikatakan profesional.

Indikator berikutnya adalah
efektifitas yang menunjukkan bahwa
auditor di lingkungan Inspektorat Provinsi Banten dalam melaksanakan penugasan audit mampu dan mengetahui dengan jelas cara mengerjakan setiap jenis tugas yang diberikan. Dengan demikian hasil audit yang dicapai menjadi lebih baik. Berdasarkan kondisi riil objek penelitian ini, profesionalisme auditor di lingkungan Inspektorat Provinsi Banten dari aspek efektifitas bisa dikatakan sudah baik, hal ini dibuktikan dengan laporan hasil audit yang telah dilaksanakan oleh auditor sudah cukup efektif dalam menggambarkan secara jelas dan gamblang mengenai hasilhasil temuan audit sesuai dengan peraturan dan perundang-undangan yang berlaku, dan hal ini sudah sesuai dengan tugas pokok dan fungsi auditor di lingkungan Inspektorat Provinsi Banten.

Hasil penelitian ini sejalan dengan penelitian Fietoria dan Manalu (2016) yang meneliti

tentang

Pengaruh

Profesionalisme,

Independensi,

Kompetensi, dan Pengalaman Kerja terhadap Kualitas Audit di Kantor Akuntan Publik Bandung, hasil penelitiannya menyatakan bahwa profesionalisme, independensi, kompetensi, dan pengalaman kerja berpengaruh terhadap kualitas audit. Hasil penelitian ini juga sejalan dengan penelitian Susilawati (2014), yang menyatakan bahwa Secara simultan Profesionalisme dan Independensi berpengaruh signifikan terhadap Kualitas Audit. Sedangkan secara parsial, Profesionalisme berpengaruh positif dan signifikan terhadap Kualitas Audit. Hasil penelitian ini membuktikan teori pengharapan bahwa upaya yang harus dilakukan auditor adalah menggunakan keahlian profesionalnya dengan cermat dan seksama (due professional care) dan hatihati (prudent) dalam pertimbangan professional (professional judgment) setiap penugasan dengan selalu mengupdate kompetensi dan memperbanyak pengalamannya serta selalu menjaga etikanya yang tercermin pada ketaatan pada standar pekerjaan lapangannya selama pelaksanaan audit. Disamping itu, selalu menjaga integritas dan independensi serta mampu menjaga dan meningkatkan 
profesionalismenya sehingga kualitas hasil audit diharapkan dapat lebih baik.

Kondisi riil Pemerintah Provinsi Banten dalam kaitan peningkatan profesionalisme para auditor di lingkungan Inspektorat Provinsi Banten saat ini sedang terus berupaya untuk meningkatkan kompetensi dan profesionalisme aparaturnya tidak terkecuali untuk para auditor yang sekarang ini sudah mencapai tingkatan Level 2 berdasarkan hasil evaluasi dan penilaian dari BPKP, pemerintah Provinsi Banten berupaya mewujudkan amanah RPJMN bahwa seluruh aparatur pengawas atau auditor di Pemerintah Provinsi pada tahun 2019 harus sudah berada di Level 3.

Selanjutnya hasil uji signifikansi koefisien jalur pada model struktural untuk variabel kompetensi menunjukkan bahwa kompetensi berpengaruh secara signifikan terhadap kualitas audit. Hal ini dibuktikan dengan nilai $t$-statistik > 1,96 (6,079> 1,96). Adapun arah pengaruh dari kompetensi terhadap kualitas audit adalah positif yang menunjukkan semakin tinggi kompetensi auditor maka akan semakin baik kualitas audit.

Pada penelitian ini indikator pengalaman dan pengetahuan adalah yang paling dominan, sementara untuk kompetensi auditor yang diukur dengan indikator keterampilan dan sikap memiliki skor yang lebih rendah dibandingkan dengan indikator pengalaman dan pengetahuan. Kemudian indikator yang memiliki skor terendah dibandingkan indikator-indikator sebelumya adalah sikap. Meskipun memiliki skor paling rendah dibandingkan indikator sebelumnya, indikator sikap auditor yang rasional dalam setiap pengambilan keputusan dan mencari solusi terhadap setiap masalah yang dihadapi berada pada kriteria yang sangat baik berdasarkan tanggapan seluruh responden dalam penelitian ini. Hal ini menunjukkan bahwa kompetensi auditor di lingkungan Inspektorat pemerintah Provinsi Banten pada seluruh aspek indikator yang digunakan dapat memberikan pengaruh yang positif terhadap kualitas audit yang dihasilkan.

Berdasarkan kondisi riil pada objek penelitian ini, kompetensi auditor di lingkungan Inspektorat pemerintah Provinsi Banten dari beberapa indikator yang digunakan dalam mengukur kompetensi auditor, secara keseluruhan auditor di lingkungan Inspektorat pemerintah Provinsi Banten bisa dikatakan sudah cukup memiliki kompetensi yang baik. Dari aspek pengetahuan, keterampilan, sikap, dan pengalaman 
seluruh auditor di lingkungan Inspektorat pemerintah Provinsi Banten yang dikatakan sudah baik ini dibuktikan dengan hasil audit yang telah dilaksanakan. Hasil audit internal ini dapat dipergunakan oleh auditor eksternal yaitu BPK RI dalam melaksanakan audit atas LKPD yang mendapatkan opini terbaik yaitu Wajar Tanpa Pengecualian berturut-turut selama empat tahun terakhir. Dengan demikian terbukti bahwa alasan kompetensi auditor berpengaruh signifikan terhadap kualitas audit yang dihasilkan.

Hasil penelitian ini mendukung dengan hasil penelitian Schelker (2012) yang menyatakan bahwa kompetensi auditor berpengaruh positif signifikan terhadap kualitas audit dan peningkatan akurasi informasi keuangan yang disampaikan kepada publik. Demikian pula dengan Fietoria dan Manalu (2016) menyatakan bahwa kompetensi memberikan pengaruh yang signifikan terhadap kualitas audit. Berbeda dengan sebelumnya, penelitian ini tidak sejalan dengan penelitian Maharany et al.,(2016) yang menyatakan bahwa kompetensi tidak berpengaruh yang signifikan terhadap kualitas audit. Hasil penelitian ini juga mendukung teori pengharapan yaitu seorang auditor dimotivasi untuk memiliki kompetensi yang cukup baik dalam menjalankan setiap pekerjaan yang pada akhirnya akan menghantarkan kepada suatu penilaian kinerja yang baik. dengan demikian dapat disimpulkan bahwa semakin baik tingkat kompetensi yang dimiliki oleh auditor akan semakin baik pula hasil kualitas audit yang dihasilkan.

\section{SIMPULAN}

Berdasarkan rumusan masalah, pengembangan hipotesis atas dasar teoriteori yang berhubungan, serta hasil analisis yang telah dibahas pada bab-bab sebelumnya, maka penulis dapat menarik simpulan sebagai berikut:

1. Profesionalisme berpengaruh positif dan signifikan terhadap kualitas audit, arah pengaruh dari variabel profesionalisme terhadap kualitas audit adalah positif, hal ini menunjukkan bahwa semakin tinggi profesionalisme auditor maka akan semakin baik kualitas audit di lingkungan Inspektorat Provinsi Banten.

2. Kompetensi Auditor pada Inspektorat Provinsi Banten berpengaruh positif dan signifikan terhadap kualitas audit internal pemerintah daerah, arah pengaruh dari kompetensi terhadap kualitas audit adalah positif, hal menunjukkan bahwa semakin tinggi kompetensi auditor maka akan semakin baik kualitas audit di 
lingkungan Inspektorat Provinsi

Banten.

Penelitian ini telah diusahakan dan dilaksanakan sesuai dengan prosedur ilmiah, namun demikian masih terdapat beberapa keterbatasan, yang kemungkinan dapat menimbulkan bias atau ketidakakuratan pada hasil penelitian ini, antara lain:

1. Faktor-faktor yang memengaruhi kualitas audit pada penelitian ini hanya terdiri dari dua variabel, yaitu profesionalisme dan kompetensi, sedangkan masih banyak faktor lain yang dapat memengaruhi kualitas audit.

2. Pada penelitian ini peneliti hanya menggunakan kuesioner, sehingga masih ada kemungkinan kelemahankelemahan yang ditemui, seperti jawaban yang kurang cermat, responden yang menjawab asal-asalan dan tidak jujur, serta pertanyaan atau pernyataan yang kurang lengkap atau kurang dipahami oleh responden yang memungkinkan tidak menunjukkan keadaan yang sesungguhnya.

3. Untuk pengembangan ilmu disarankan bagi penelitian selanjutnya untuk dapat memasukan variabel lain yang berpengaruh terhadap kualitas audit, yaitu faktor budaya kerja, serta etika profesi yang tidak penulis masukkan sebagai variabel dalam penelitian ini.

\section{DAFTAR PUSTAKA}

A. A Anwar Prabu Mangkunegara (2012). Manajemen Sumber Daya Manusia. Bandung: PT. Remaja Rosdakarya.

Arena M, Azzone G. 2009. Identifying Organizational Drivers of Internal Audit Effectiveness. International Journal Audit.13:43-60.

Arens, Alvin A., Elder, dan Beasley. 2015. Auditing dan Jasa Assurance Pendekatan Terintegrasi Jilid 1 . Edisi 15. Jakarta: Erlangga.

Asosiasi Auditor Internal Pemerintah Indonesia (AAIPI). 2014. Standar Audit Intern Pemerintah Indonesia

Badan Pemeriksa Keuangan Republik Indonesia Tahun 2007. Peraturan Badan Pemeriksa Keuangan RI Nomor 01 Tahun 2007 tentang Standar Pemeriksaan Keuangan Negara.

Badan Pengawasan dan Keuangan dan Pembangunan (BPKP). 2015. Laporan Hasil Evaluasi Pemetaan APIP Kementerian, Lembaga dan Pemerintah Daerah. BPKP.

COSO. 1992. Internal Control-Integrated Framework. Committee of Sponsoring Organizations Of The Tread way Commission.

Endaya AK, Hanefah MM. 2013. Internal Audit Effectiveness: An Approach Proposition To Develop The Theoretical Framework. Research Journal of Finance and Accounting. 4(10):92-103.

Fauziah. 2017. Pengaruh Kompetensi, Independen, dan Motivasi terhadap Kualitas Audit dalam Pengawasan Keuangan Daerah (Studi Empiris 
Pada Auditor BPKP Perwakilan Provinsi Sumatera Utara). Riset dan Jurnal Akuntansi Vol.1 No.1 Februari 2017.

Fietoria, Manalu Elisabeth Stefany. 2016. Pengaruh Profesionalisme, Independensi, Kompetensi, dan Pengalaman Kerja Terhadap Kualitas Audit di Kantor Akuntan Publik Bandung. Journal of Accounting and Business Studies. Vol. 1, No. 1.

Futri, Putu Septiani, (2014). "Pengaruh independensi, profesionalisme, tingkat pendidikan, etika profesi, pengalaman, dan kepuasan kerja auditor pada kualitas audit kantor akuntan publik di bali". Universitas Udayana, E-Jurnal Akuntansi Universitas Udayana 7.2 (2014): 444-461 : Bali

George R. Terry, 2012, Asas-asas Manajemen, cetakan ketujuh, PT Alumni, Bandung.

Ghozali, Imam dan Hengky Latan. 2015. Partial Least Squares Konsep, Teknik dan Aplikasi Menggunakan Program SmartPLS 3.0 Untuk Penelitian Empiris. Edisi ke 2. Badan Penerbit UNDIP Semarang.

Hitt, Michael Dan AR. 1999. Strategic Management : Competitiveness \& Globalization.

Karnisa, Ditia Ayu. 2015. Pengaruh Kompetensi dan Independensi Terhadap Kualitas Audit dengan Motivasi dan Etika Auditor Sebagai Variabel Moderasi. Skripsi Universitas Diponegoro Semarang.

Maharany, Yuli Widi Astuti, Dodik Juliardi. 2016. Pengaruh Kompetensi, Independensi Dan Etika Profesi Auditor Terhadap Kualitas Audit (Studi Empiris Pada Kap Di Malang). Jurnal Akuntansi
Akrual. Vol.3 No.3, Januari 2016, hal. 236-242.

Moeheriono. 2010. Pengukuran Kinerja Berbasis Kompetensi. Surabaya: Ghalia Indonesia.

Narimawati, Umi. 2010. Metodologi Penelitian Kualitatif dan Kuantitatif Teori dan Aplikasi. Bandung. Agung Media.

Pemerintah Republik Indonesia. 2010. PP. No. 71 Tahun 2010 tentang Standar Akuntansi Pemerintahan. Jakarta.

Peraturan Pemerintah Nomor 60 Tahun 2008 tentang Sistem Pengendalian Intern Pemerintah. Jakarta.

Pusdiklatwas BPKP. 2005. Kode Etik dan Standar Audit. Edisi Keempat.

Rosalina, Amalia Dewi. 2015. Pengaruh Kompetensi dan Indipendensi Auditor Terhadap Kualitas Audit (Pada kantor Akuntan Publik di Wilayah Bandung). Jurnal Universitas Widyatama.

Schelker, Mark. 2012. Auditor expertise: Evidence from the public sector. Economic Letter 116 (2012) 432435.

Sedarmayanti. (2004), Sumber Daya Manusia dan Produktivitas Kerja.Bandung: Mandar Maju

Sugiyono, 2013, Metodelogi Penelitian Kuantitatif, Kualitatif Dan $R \& D$. (Bandung : ALFABETA)

Susilawati (2014). "Pengaruh profesionalisme dan independensi auditor internal terhadap kualitas audit: studi pada inspektorat Propinsi jawa barat"

Wakhyudi. 2012. Pemberdayaan Peran Audit Internal dalam Mewujudkan Good Governance pada Sektor Publik. 